\title{
PENGARUH KOMBINASI BAHAN PENYAMAK FORMALIN DAN SYNTAN TERHADAP KUALITAS KULITI IKAN PARI TERSAMAK
}

\author{
(THE INFLUENCE OF COMBINATION OF FORMALIN AND \\ SYNTAN AS TANNING AGENT ON THE QUALITY OF TANNED \\ STINGRAY LEATHER)
}

\author{
Latif Sahubawa1), Ambar Pertiwiningrum², Adityo Triarso Pamungkas ${ }^{2)}$ \\ Email: Latifsahubawa2004@yahoo.com \\ Diterima: 13 Desember 2010 \\ Disetujui: 13 September 2011
}

\begin{abstract}
This research aimed to determine the effect of the combination of tanning materials (formalin and syntan) to the quality of tanned stingray leather. Compositions of tanning materials that being tested were: $4 \%$ formalin $+6 \%$ syntan (sample A), $4 \%$ formalin $+8 \%$ syntan (sample B), $6 \%$ formalin $+6 \%$ syntan (sample C) and $6 \%$ formalin $+8 \%$ syntan (sample D). Test parameters that were observed: the tensile strength $\left(N / \mathrm{cm}^{2}\right)$, tear strength $(\mathrm{N} / \mathrm{cm})$, shrinkage temperature $\left({ }^{\circ} \mathrm{C}\right)$, content oil / fat $(\%)$, and water content $(\%)$. Data results were then compared with standard value from of stingray tanned leather from SNI (Indonesian National Standard) SNI. 06-6121-1999. The compared data were then analyzed by variance analysis with significantly of $95 \%(\alpha .0 .05)$. Results from variance analysis showed that a combination of tanning agent $B(4 \%$ formalin, syntan $8 \%$ ) was the best treatment material to produce the best result, with tensile strength at 2,810,08 N/cm2, tear strength at $672.96 \mathrm{~N} / \mathrm{cm}$, wrinkle temperature at $79.67{ }^{\circ} \mathrm{C}$, moisture content at $14,99 \%$ and fat content at $4.38 \%$. The results suggest that the combination of $4 \%$ formalin, syntan $8 \%$ produce the best result of all test parameters therefore making the tanned stingray leather qualify the requirements of SNI standard 06-6121-1999 to be used as raw materials for leather goods.
\end{abstract}

Keywords: comỏination, tanning agent, formalin, syntan, quality, tanned stringray leather

\begin{abstract}
ABSTRAK
Penelitian bertujuan untuk mengetahui pengaruh kombinasi bahan penyamak (formalin dan syntan) terhadap kualitas sampel kulit ikan pari tersamak. Perlakuan yang dicobakan masing-masing: campuran formalin $4 \%+\operatorname{syntan} 6 \%$ (A), campuran formalin $4 \%+\operatorname{syntan} 8 \%$ (B), campuran formalin $6 \%+\operatorname{syntan} 6 \%$ (C), dan campuran formalin $6 \%+\operatorname{syntan} 8 \%$ (D). Parameter uji yang diamati meliputi: kekuatan tarik $\left(\mathrm{N} / \mathrm{cm}^{2}\right)$, kekuatan sobek $(\mathrm{N} / \mathrm{cm})$, suhu kerut $\left({ }^{\circ} \mathrm{C}\right)$, kadar minyak/lemak (\%), dan kadar air (\%). Data hasil penelitian dibandingkan dengan SNI kulit pari tersamak (SNI. 06-6121-1999), kemudian dianalisis dengan analisa varian pada tingkat kepercayaan $95 \%(\alpha, 0,05)$. Hasil analisa varian menunjukkan bahwa kombinasi bahan penyamak (formalin 4\%, syntan $8 \%$ ) merupakan perlakuan terbaik dengan nilai kekuatan tarik $2.810,08 \mathrm{~N} / \mathrm{cm}^{2}$, kekuatan sobek $672,96 \mathrm{~N} / \mathrm{cm}$, suhu kerut $79,67{ }^{\circ} \mathrm{C}$, kadar air $14,99 \%$, kadar lemak 4,38 \%, dan telah memenuhi persyaratan SNI 06-6121-1999, sebagai bahan baku kulit tersamak untuk barang kulit.
\end{abstract}

Kata kunci: kombinasi, bahan penyamak, formalin, syntan, kualitas, kulit ikan pari tersamak

PENDAHULUAN

Perairan Laut Indonesia memiliki sumber daya perikanan sangat besar, berpotensi ekonomi untuk peningkatan pendapatan dan kesejaheraan nelayan, namun kenyataannya masih jauh dari harapan. Sering

1) Jurusan Perikanan, Faluiltas Pertanian UGM, ${ }^{2)}$ Falcaltas Peternakan UGM 
menjadi berita hangat bahwa masyarakat nelayan hidup dalam kondisi serba kekurangan (marginal) sehingga tidak mampu memberikan kebutuhan sosial-ekonomi keluarga yang layak. Kondisi tersebut tidak lepas dari rendahnya Ipteks, keterbatasan modal, serta fasilitas dalam mengembangkan usaha perikanan. Peningkatan kesejahteraan nelayan diusahakan melalui pemberdayaan keterampilan keluarga nelayan dalam mengolah hasil samping penangkapan. Salah satu model pemberdayaan yaitu peningkatan keterampilan penyamakan kulit, terutama kulit ikan pari yang memiliki nilai jual tinggi.

Hasil sampingan kulit ikan pari dapat ditingkatkan nilai ekonominya melalui teknik penyamakan untuk menghasilkan bahan baku kulit (kulit stabil), sebagai upaya peningkatan pendapatan dan kesejahteraan nelayan, karena dapat diolah menjadi barang jadi seperti dompet, tas, jaket, ikat pinggang, sepatu, dan produk kulit lainnya yang bernilai ekonomis. Produk kulit yang dihasilkan memiliki ciri khas dimana terdapat manik-manik dan butiran mutiara keras pada permukaan kulit yang berkilau-kilau dengan daya tarik yang menakjubkan (Tambunan, 1992 ; Sahubawa dan Pertiwiningrum, 2008). Menurut (Untari, 1997) serta (Sahubawa dan Pertiwiningrum, 2008), ikan pari mempunyai kulit dan rajah yang menarik setelah disamak dan diolah menjadi produk karena adanya manik-manik dan mutiara yang tidak dimiliki jenis ikan lain serta memperlihatkan orisinilitas produk.

Ikan pari hasil sampingan penangkapan (by-catch) jaring purse-seine, gill-net, dan trawl yang selama ini belum dimanfaatkan secara optimal sebagai sumber penghasilan nelayan, ternyata dapat diolah menjadi bahan baku industri dan berbagai produk yang memiliki nilai tambah (value-added) sangat besar untuk pasar lokal maupun ekspor. Jenis by-catch ini dirasakan sangat penting dan mendesak untuk dimanfaatkan sebagai bahan baku kulit non konvensional untuk produk turunan sebagai usaha ekonomi produk masyarakat. Ikan pari merupakan salah satu hasil tangkapan nelayan yang didaratkan sepanjang tahun dengan produksi cukup tinggi di setiap tempat pendaratan ikan (TPI) di Indonesia dan khususnya di pantai Selatan Pulau Jawa (Sahubawa, 2007).
Penyamakan kulit adalah teknik pengolahan untuk mengubah kulit mentah hewan besar (hides) dan hewan kecil (skins) yang bersifat labil menjadi kulit tersamak (leather) yang stabil terhadap perubahan dan atau perlakuan fisik (suhu dan kelembaban), kimia (bahan kimia reaktif), serta mikrobiologis (bakteri, kapang, dan jamur) sehingga kulit tersamak menjadi awet, kuat serta dapat dipakai untuk bahan baku produk kulit (Tambunan, 1992; Untari, 1997 ; Sahubawa dan Pertiwiningrum, 2008). Kulit ikan pari yang dimanfaatkan hanya bagian punggung yang memiliki manik-manik dan mutiara. Pada proses penyamakan, butiran manik-manik dan mutiara harus dipertahankan tetap utuh, sehingga dapat diolah menjadi produk kulit yang menarik. Mutu kulit pari tersamak sangat baik, serta lebih kuat dan tahan terhadap perubahan fisik, kimia dan mikrobiologis dikembangkan jenis kulit lainnya, berpola spesifik, bahkan sangat menarik dan memiliki nilai ekonomi tinggi dibandingkan kulit konvensional (kerbau, sapi, domba, kambing, dan lain-lain). Pola yang spesifik pada kulit ikan pari, menjadikan produk kulit pari lebih istimewa, bahkan memiliki dayatarik (preferensi) konsumen yang cukup besar (Sahubawa dan Periwiningrum, 2008). Agar limbah kulit ikan pari dapat dimanfaatkan dan diaplikasikan nelayan sebagai usaha ekonomi produktif alternatif, maka diperlukan penelitian lebih lanjut tentang efektivitas campuran bahan penyamak formalin dan syntan.

Penyamakan kombinasi adalah penggunaan dua atau lebih bahan penyamak sebagai suatu perlakuan dalam proses penyamakan untuk menghasilkan kulit tersamak yang berkualitas tinggi. Penggunaan campuran bahan penyamak bertujuan untuk memperbaiki dan meningkatkan kualitas kulit tersamak karena masing-masing bahan penyamak dapat saling menutupi kekurangan sifat melalui keunggulan yang dimiliki. Syntan menghasilkan kulit tersamak yang cukup lemas dan cerah, sedangkan formalin menghasilkan kulit tersamak dengan sifat kelemasan, kekuatan tarik, dan kekuatan sobek yang tinggi (Purnomo, 1991). 
Tujuan penelitian adalah: mengetahui pengaruh kombinasi bahan penyamak formalin dan syntan terhadap kualitas fisikkimia kulit ikan pari tersamak. Manfaat yang diharapkan adalah sebagai salah satu sumber pendapatan alternatif untuk nelayan serta sebagai usaha ekonomi produktif untuk investor yang tertarik di bidang pengolahan produk kulit ikan khususnya dan produk kulit umumnya.

\section{BAHAN DAN METODE \\ Bahan Penelitian}

Bahan baku utama yaitu kulit ikan pari segar yang berasal dari nelayan Pantai Gesing Gunungkidul, bahan penyamak formalin dan syntan, air leding, enzim pankreas sapi yang diperoleh dari Rumah Potong Hewan (RPH) Fakultas Peternakan UGM, $\mathrm{Na}_{2} \mathrm{CO}_{3}, \mathrm{Na}_{2} \mathrm{~S}$, amonium sulfida, minyak sintetis, teefol, $\mathrm{NaHCO}_{3}, \mathrm{Ca}(\mathrm{OH})_{2}, \mathrm{HCOOH}, \mathrm{H}_{2} \mathrm{SO}_{4}$, antiseptik, garam, dan bahan tambahan lainnya.

\section{Alat Penelitian}

Peralatan yang digunakan yaitu: ember plastik, pisau seset (pisau fleshing), timbangan, gelas ukur, mangkuk, kertas $\mathrm{pH}$, termometer, sarung tangan, alat peregang kulit (stacking manual), papan pentang, softness tester merk, tensile strength merk.

\section{Cara Percobaan}

Penelitian didesain dengan 4 (empat) perlakuan campuran bahan penyamak, masing-masing: perlakuan A (campuran formalin $4 \%+\operatorname{syntan} 6 \%$ ) ; perlakuan B (campuran formalin $4 \%+$ syntan $8 \%$ ); perlakuan $\mathrm{C}$ (campuran formalin $6 \%+$ syntan $6 \%$ ); dan perlakuan D (campuran formalin 6 $\%+$ syntan $8 \%$ ). Masing-masing perlakuan dibuat 3 (tiga) kali pengulangan analisa dengan tujuan untuk mendapatkan data yang lebih valid.

\section{Pelaksanaan Penelitian}

Pelaksanaan penelitian dilakukan dengan tahap sebagai berikut:

1. Pengawetan kulit.

Sampel kulit ikan pari diawetkan dengan garam kristal secara berlapis dalam boks penyimpanan sampel, disimpan dalam cold-storage selama 1 (satu) minggu.
2. Penyiapan sampel.

Keluarkan sampel kulit dalam boks yang disimpan dalam cold-storage, cuci dalam air mengalir untuk menghilangkan garam dan mencairkan kebekuan kulit.

3. Sampel kulit dilakukan proses perendaman dalam larutan teepol (air 200 $\%$, NaHCO 0,5 \%, teepol 0,5 \%), aduk/diputar \pm 20 menit, selanjutnya dicuci dengan air mengalir sampai bersih.

4. Pengapuran.

Sampel kulit dilakukan proses pengapuran dalam larutan kapur (400\% air, $2 \% \mathrm{Na} 2 \mathrm{~S}$ ), diaduk selama 30 menit, tambah $6 \%$ kapur, dan aduk selama 20 menit, diamkan selama 60 menit, aduk selama 10 menit, diamkan selama 60 menit, simpan selama 24 jam, aduk selama 30 menit, kemudian cuci bersih dengan air mengalir

5. Pembuangan daging.

Kulit disikat dengan sikat kawat sampai bersih, cuci dengan air mengalir hingga bersih, kemudian hilangkan dagingnya.

6. Pengapuran ulang.

Kulit direndam dalam larutan kapur (400 $\%$ air, $6 \%$ kapur, 0,5\% teepol), aduk selama 10 menit, diamkan selama 60 menit (diulangi 2 kali), dibiarkan selama satu malam, kemudian disikat dan dicuci hingga kulit bersih.

7. Pembuangan kapur.

Kulit direndam dalam larutan $(400 \%$ air, $2 \%$ ZA), diaduk selama 30 menit, ditambahkan 0,5 \% FA dalam larutan secara bertahap sambil diaduk selama 15 menit, kemudian uji pH larutan (7-8).

8. Pembuangan lemak/minyak.

Masukkan sampel kulit dalam larutan teepol, tambahkan larutan bating sebanyak $1 \%$, aduk selama 30 menit, kemudian cuci bersih.

9. Pengikisan protein.

Sampel kulit direndam dalam larutan kimia hasil proses pembuangan kapur, ditambahkan dengan enzim, diaduk selama 60 menit, kemudian uji dengan thumb test dengan cara menekan kulit.

10. Pengasaman.

Sampel kulit dimasukkan dalam larutan (200\% air, $17 \%$ garam dan 0,5\% minyak), aduk selama 10 menit, 
tambahkan $1 \%$ FA (secara bertahap, 2 kali) dengan pengadukan selama 15 menit, tambahkan 1,5\% asam sulfat (secara bertahap, 3 kali) dengan selang waktu 15 menit, diaduk selama 60 menit (periksa $\mathrm{pH}$ \pm 3 ), aduk kembali selama 1 jam, kemudian rendam semalam. Hari berkutnya, sampel diaduk selama 30 menit dengan control $\mathrm{pH}$ 3,5-4,0.

11. Penyamakan.

Sampel kulit direndam dalam $200 \%$ larutan pickle, tambah $1 \%$ soda kue, aduk selama 20 menit (pada 2 tahap), masing-

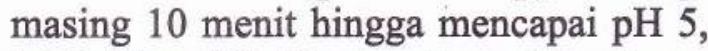
tambahkan $0,5 \%$ minyak, aduk selama 10 menit, tambahkan perlakuan (perbandingan campuran formalin dan syntan: $4 \%: 6 \% ; 4 \%: 8 \% ; 6 \%: 6 \% ; 6 \%: 8$ $\%$ ), aduk selama 3 jam, tambahkan 1,5\% soda kue ( 3 tahap) masing-masing selama 20 menit, aduk kembali selama 3 jam, tes $\mathrm{pH} \pm 7$, diamkan selama satu malam. Hari berikutnya, aduk kembali selama 30 menit Untuk mengetahui kematangan kulit, dilakukan boiling test dengan cara memasukkan kulit pada air panas bersuhu $75-80^{\circ} \mathrm{C}$, selanjutnya sampel kulit dicuci bersih.

12. Netralisasi.

Masukkan sampel kulit dalam larutan $\mathrm{NaHCO}_{3}$ 1,5 \%, tambahkan air Untuk mengetahui kematangan kulit, dilakukan boiling test dengan cara memasukkan kulit pada air panas bersuhu $70-80{ }^{\circ} \mathrm{C}$, selanjutnya sampel kulit dicuci bersih.

13.Penyamakan ulang.

Sampel kulit dimasukkan dalam $200 \%$ air hangat bersuhu $40{ }^{\circ} \mathrm{Cditambah}$ bahan syntan $6 \%$, diaduk selama 60 menit, kemudian dicuci bersih.

14. Peminyakan.

Sampel kulit direndam dalam $200 \%$ air hangat dengan suhu $60^{\circ} \mathrm{C}$, tambahkan $6 \%$ minyak sulfonasi, aduk selama 90 menit, tambahkan $1 \%$ FA dan aduk selama 20 menit. Periksa $\mathrm{pH}$ larutan $(\mathrm{pH} 3-4)$, kemudian dicuci bersih.

15. Selanjutnya ampel kulit dilakukan aging, stacking, dan brushing.

16. Pembasahan ulang.

Sampel kulit dilakukan pembasahan ulang $400 \%$ air hangat (suhu $40{ }^{\circ} \mathrm{C}$ ), ditambah wetting agent, 0,5 \% ammoniak, diaduk selama 30 menit dan cuci bersih. Rendam kembali dalam air hangat sebanyak $400 \%$, aduk selama 10 menit, selanjutnya dicuci bersih.

17. Pewarnaan.

Pewarnaan dasar dilakukan menggunakan air $50 \%$ dan cat dasar $1 \%$, dan diaduk selama 60 menit tambahkan $1 \%$ FA aduk selama 20 menit.

18. Finishing.

Sebelum dilakukan finishing dilakukan pengeringan, pementangan, pelemasan, dan pengamplasan.

\section{Parameter Uji}

Parameter uji yang diamati sesuai SNI. 06-6121-1999 (peruntukkan kulit pari sebagai bahan baku barang kulit), yaitu: kekuatan tarik $\left(\mathrm{N} / \mathrm{cm}^{2}\right)$, kekuatan sobek $(\mathrm{N} / \mathrm{cm})$, suhu kerut $\left({ }^{\circ} \mathrm{C}\right)$, kadar lemak/minyak (\%), dan kadar air (\%).

\section{Metode Analisis Data}

Data hasil uji dari 4 (empat) perlakuan yang dicobakan, dibandingkan dengan SNI 06-6121-1999, dengan tujuan mengkaji mutu kulit pari tersamak yang dihasilkan sebagai bahan baku barang kulit. Selanjutnya, data hasil pengamatan diuji secara statistik dengan analisis sidik ragam untuk melihat pengaruh faktor sebagai sumber perlakuan serta uji perbandingan berganda (Uji BNJ) dengan tujuan untuk melihat perbedaan antar perlakuan terhadap kualitas kulit pari tersamak pada tingkat signifikansi $95 \%$.

\section{HASIL DAN PEMBAHASAN \\ Kekuatan Tarik (Tensile Strength, N/cm²)}

Kekuatan tarik adalah besarnya gaya tarik maksimal alat untuk menarik kulit sampai putus $\left(\mathrm{N} / \mathrm{cm}^{2}\right)$. Hasil pengujian sifat kekuatan tarik sampel kulit ikan pari tersamak dari masing-masing perlakuan: A (formalin 4 $\%+\operatorname{syntan} 6 \%$ ), B (formalin $4 \%+$ syntan $8 \%$ ), C (formalin $6 \%+$ syntan $6 \%$ ), dan D (formalin 6\% + syntan $8 \%$ ) yaitu: $2.168,04$ $\mathrm{N} / \mathrm{cm}^{2} ; 2.810 .08 \mathrm{~N} / \mathrm{cm}^{2} ; 2.263,72 \mathrm{~N} / \mathrm{cm}^{2}$; dan $2290.95 \mathrm{~N} / \mathrm{cm}^{2}$. Nilai kekuatan tarik cenderung meningkat sejalan dengan peningkatan penggunaan konsentrasi bahan penyamak, dan nilai tertinggi dihasilkan pada 
perlakuan B (Gambar 1). Nilai yang dihasilkan lebih tinggi dibandingkan dengan SNI 06-6121-1999. Berdasarkan hasil uji BNJ pada tingkat signifikansi $95 \%$, terlihat ada pengaruh nyata dari perlakuan yang dicobakan terhadap nilai kekuatan tarik sampel kulit pari tersamak. Menurut SNI 06-6121-1999, standar nilai kekuatan tarik kulit ikan pari untuk barang kulit minimal $2000 \mathrm{~N} / \mathrm{cm}^{2}$.

Hasil penelitian menunjukkan bahwa semua perlakuan yang dicobakan dapat menghasilkan nilai kekuatan tarik cenderung meningkat sejalan dengan peningkatan penggunaan konsentrasi bahan penyamak, dan nilai tertinggi dihasilkan pada perlakuan B (Gambar 1). Nilai yang dihasilkan lebih tinggi dibandingkan dengan SNI 06-6121-1999. Berdasarkan hasil uji BNJ pada tingkat signifikansi $95 \%$, terlihat ada pengaruh nyata dari perlakuan yang dicobakan terhadap nilai kekuatan tarik sampel kulit pari tersamak. Menurut SNI 06-6121-1999, standar nilai kekuatan tarik kulit ikan pari untuk barang kulit minimal $2000 \mathrm{~N} / \mathrm{cm}^{2}$.

Hasil penelitian menunjukkan bahwa semua perlakuan yang dicobakan dapat menghasilkan nilai kekuatan tarik yang memenuhi persyaratan SNI. Hal ini diduga kuat terkait dengan reaktivitas bahan penyamak (formalin dan syntan) dalam mematangkan serat-serat kolagen sehingga dapat menghasilkan kulit dengan kualitas terbaik.

Formalin mengandung aldehida dengan kadar $10-40 \%$ dengan rumus kimia $\mathrm{H}_{2} \mathrm{CO}$, sifatnya berupa gas dapat bereaksi dengan gugus fungsional $\mathrm{NH}_{2}$ secara sempurna sehingga mampu merubah sifat-sifat fisik protein kolagen (Anonim, 2009). Sarphause cit Untari (2001), mengatakan bahwa syntan memiliki kemampuan ionisasi yang tinggi dalam proses penyamakan dibandingkan bahan penyamak lainnya (mimosa) sehingga terjadi gaya tarik-menarik (ikatan) yang kuat dengan protein kolagen. Syntan memiliki zat aktif kompleks (poly hidroxy benzoles) yang memiliki gugus hidroksil (bermuatan positif dan negatif) dalam jumlah besar sehingga makin banyak gugus fungsional protein kolagen yang terikat dengan syntan untuk menghasilkan kulit tersamak dengan kualitas yang lebih baik.

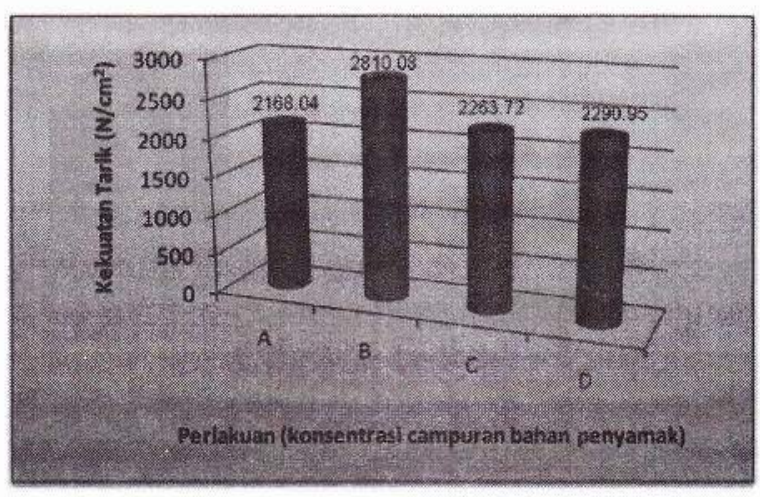

Gambar 1. Kekuatan tarik sampel kulit ikan pari tersamak pada setiap perlakuan

\section{Kekuatan Sobek (Tearing Strength, N/cm)}

Kekuatan sobek kulit adalah besarnya gaya maksimal yang diperlukan alat untuk menyobek sampel sampai tersobek semua (SNI 06-6121-1999). Hasil pengujian sifat kekuatan sobek sampel kulit ikan pari tersamak masing-masing perlakuan sebagai berikut: $A=699,86 \mathrm{~N} / \mathrm{cm} ; \mathrm{B}=672,96 \mathrm{~N} / \mathrm{cm}$; $\mathrm{C}=865,85 \mathrm{~N} / \mathrm{cm}$ dan $\mathrm{D}=1.036 .65 \mathrm{~N} / \mathrm{cm}$.

Hasil analisis tersebut memperlihatkan bahwa makin besar penambahan perbandingan bahan penyamak formalin dan syntan, makin tinggi nilai kekuatan sobek sampel kulit pari (Gambar 2). Hal ini diduga kuat terkait dengan tingginya konsentrasi bahan penyamak yang diberikan makin banyak bahan aktif yang berikatan dengan serat-serat protein kolagen sehingga makin matang dan padat serat-serat yang dibentuk, yang pada akhirnya makin kuat (tahan putus dan tahan sobek) kulit pari tersamak yang dihasilkan.

Penggunaan formalin dan syntan pada konsentrasi $>7,5 \%$ dalam proses penyamakan mampu diserap secara sempurna karena sifatsifat ionisasi yang tinggi terhadap asam amino (protein) kolagen kulit pada kisaran $\mathrm{pH}$ yang luas, serta memiliki kekuatan daya ionik tarikmenarik melalui penyusutan air yang stabil sehingga menghasilkan kulit yang padat (Anonim, 2010). Lebih lanjut dikatakan Anonim (2010), bahwa formalin dan syntan larut dan terionisasi secara sempurna dalam air, stabil terhadap semua bahan penyamak serta mampu berikatan dengan protein secara kuat dan sempurna sehingga dapat menghasilkan kulit yang padat dan kuat. 
Dari hasil uji BNJ tingkat signifikansi 95 $\%$, terlihat tidak terdapat beda nyata nilai kekuatan sobek dari masing-masing perlakuan percobaan. Menurut SNI 06-6121-1999, standar nilai kekuatan sobek kulit pari tersamak untuk produk barang kulit minimal $300 \mathrm{~N} / \mathrm{cm}$. Dari hasil penelitian menunjukkan bahwa semua perlakuan yang dicobakan dapat menghasilkan nilai kekuatan sobek yang memenuhi persyaratan SNI.

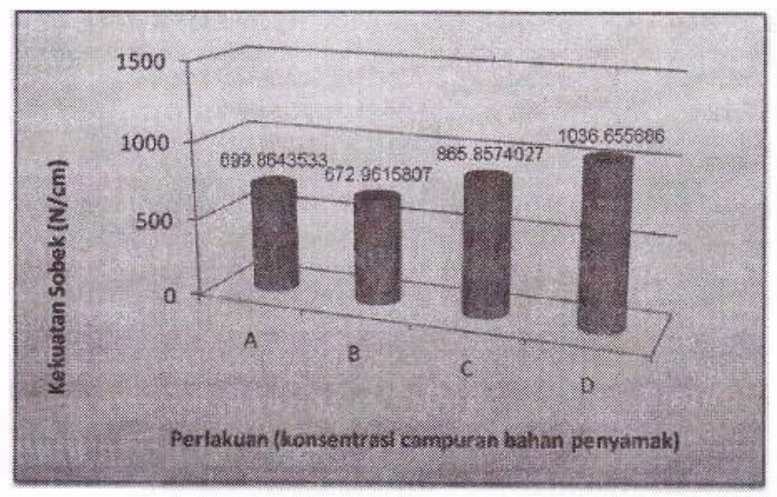

Gambar 2. Kekuatan sobek kulit ikan pari tersamak pada setiap perlakuan

\section{Suhu Kerut (Shrinkage Temperature, ${ }^{\circ} \mathrm{C}$ )}

Suhu kerut adalah suhu kulit tersamak saat sampel mengalami pengkerutan dengan cara pemanasan bertahap dalam medium air (Judoamidjojo, 1982), atau dengan kata lain suhu dimana terjadi pengkerutan struktur kolagen kulit.

Hasil pengujian suhu kerut sampel kulit pari tersamak setiap perlakuan sebagai berikut: $76,67^{\circ} \mathrm{C} ; 79,67^{\circ} \mathrm{C} ; 76,67^{\circ} \mathrm{C}$; dan 76 ${ }^{0} \mathrm{C}$.

Menurut SNI 06-6121-1999, standar suhu kerut kulit pari tersamak sebagai bahan baku produk kulit minimal $70{ }^{\circ} \mathrm{C}$. Hal ini menunjukkan bahwa suhu kerut sampel kulit pari dari setiap perlakuan memenuhi SNI. Kisaran nilai yang dihasilkan masing-masing perlakuan tidak memperlihatkan kecenderungan peningkatan dan atau penurunan sejalan dengan pertambahan konsentrasi bahan penyamak (hampir sama untuk setiap perlakuan), tetapi hanya perlakuan B yang menghasilkan nilai suhu kerut tertinggi (Gambar 3).
Dari hasil uji BNJ pada tingkat signifikansi $95 \%$, diketahui tidak terdapat beda nyata nilai suhu kerut dari masingmasing perlakuan. Suhu kerut erat kaitan dengan kematangan kulit, dimana makin banyak serat-serat kulit yang matang akibat penetrasi bahan penyamak, makin tinggi suhu kerut kulit tersamak. Makin tinggi suhu kerut kulit, makin tinggi ketahanan kulit terhadap panas (hidrothermal) sehingga makin tinggi kualitas kulit yang dihasilkan (Kurniani dkk, 2007). Besarnya ketahanan kulit tesamak terhadap panas dipengaruhi oleh jenis dan jumlah bahan penyamak yang berikatan dengan serat-serat kolagen kulit. Pengkerutan terjadi karena adanya lipatan rantai polipeptida akibat putusnya ikatan antar anyaman serabut karena kondisi ekstrim seperti pemanasan pada suhu tinggi (Sarkar, 1995 cit. Ayufita, 2007).

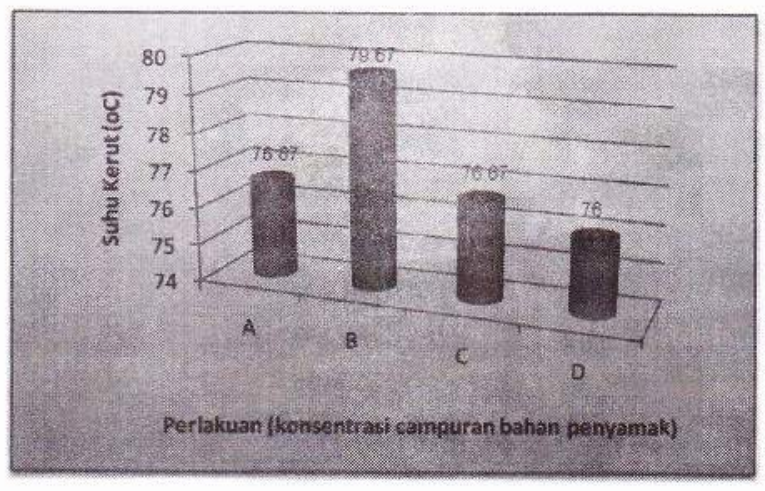

Gambar 3. Suhu kerut kulit pari tersamak pada setiap perlakuan

\section{Kadar Air (\%)}

Hasil pengujian kadar air sampel kulit pari tersamak dari perlakuan $\mathrm{A}=15,99 \% ; \mathrm{B}=$ $14,99 \% ; C=15,00 \%$ dan $\mathrm{D}=15 \%$. Nilai kadar air sampel kulit ikan pari tersamak memenuhi standar mutu SNI 06-6121-1999, yakni maksimal $20 \%$. Data hasil uji kadar air kulit ikan pari tersamak pada semua perlakuan telah memenuhi standar produk kulit. Kadar air sampel kulit pari tersamak dari setiap perlakuan dapat dilihat pada Gambar 4 .

Hasil uji BNJ pada tingkat signifikansi $95 \%(p>0,05)$, menunjukkan bahwa tidak terdapat perbedaan nyata antar perlakuan percobaan, artinya interval nilai rerata yang dihasilkan antar perlakuan tidak 
memperlihatkan sifat korelatif tehadap perubahan kadar air.

Menurut (Judoamidjojo, 1982), molekul air dalam kulit tersamak memiliki 2 (dua) pengaruh, yakni akan mempengaruhi kematangan serat protein kolagen karena terjebak dalam sudut-sudut heliks yang berdampak pada rendahnya nilai kekuatan tarik dan kekuatan sobek, serta sebagai media tumbuhnya mikrobia (terutama kapang) pada produk yang rendah kadar air. Untuk menghilangkan kadar air pada sudut ikatan heliks protein kolagen tersebut, kulit tersamak dapat dipanaskan dalam oven bersuhu 50-60 ${ }^{\circ} \mathrm{C}$ selama waktu tertentu.

\section{Kadar Lemak/Minyak (\%)}

Hasil pengujian kadar minyak/lemak sampel kulit pari tersamak dari masingmasing perlakuan yaitu: $A=3,16 \% ; B=4,38$ $\%$; $C=4,04 \% ; D=6,06 \%$. Kadar minyak sampel kulit ikan ikan pari tersamak hasil penelitian telah memenuhi SNI yang mempersyaratkan maksimal $12 \%$. Kadar lemak/minyak sampel kulit ikan pari tersamak dari setiap perlakuan diperlihatkan pada Gambar 5, dimana terdapat kecenderungan peningkatan kadar minyak/lemak sejalan dengan peningkatan konsentrasi bahan penyamak. Hal ini menunjukkan bahwa makin tinggi konsentrasi bahan penyamak, makin rendah kualitas kulit ikan pari tersamak. Meskipun demikian, perlakuan C menghasilkan kadar minyak/lemak lebih rendah dibandingkan perlakuan $B$.

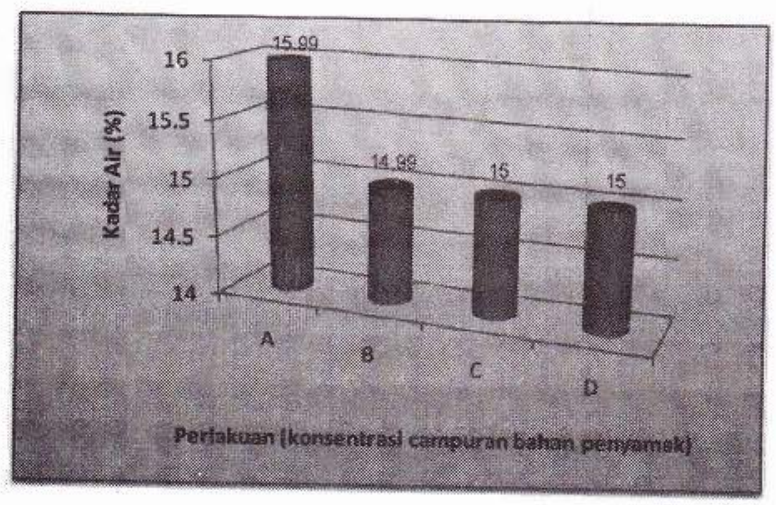

Gambar 4. Kadar air kulit ikan pari tersamak tiap perlakuan.

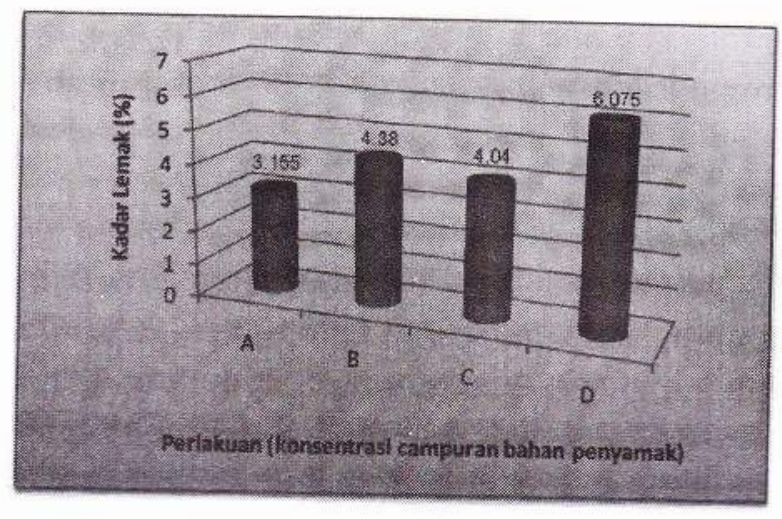

Gambar 5. Kadar minyak/lemak kulit pari tersamak tiap perlakuan

Berdasarkan hasil uji BNJ pada taraf signifikansi $95 \%$, diketahui tidak terdapat beda nyata nilai kadar lemak/minyak dari tiaptiap perlakuan, artinya interval nilai rerata yang dihasilkan antar perlakuan tidak memperlihatkan sifat korelatif, sejalan dengan peningkatan dan atau penurunan konsentrasi bahan penyamak terhadap kadar minyak/lemak sampel kulit pari tersamak. Kandungan minyak yang tinggi di bagian bawah permukaan kulit menjadi penghambat penetrasi bahan penyamak ke dalam seratserat kolagen kulit. Jika kadar minyak/lemak pada kulit tersamak atau produk kulit relatif tinggi, maka kemungkinan dapat menimbulkan bau tengik jika dibiarkan di udara terbuka atau terkena sinar matahari. Hal ini disebabkan terjadi proses hidrolisis dengan uap air yang menghasilkan asam lemak bebas. Pembentukan asam lemak (terutama lemak tidak jenuh) akan menimbulkan reaksi oksidasi. Oksidasi asam lemak tidak jenuh dapat menghasilkan peroksida dan selanjutnya terbentuk aldehida yang menimbulkan bau tidak enak atau (tengik). Kelembaban udara, cahaya, suhu tinggi adalah faktor penyebab meningkatnya ketengikan lemak (Poedjiadi, 1994).

\section{KESIMPULAN DAN SARAN Kesimpulan}

1. Berdasarkan hasil analisis, nilai kekuatan tarik, kekuatan sobek, suhu kerut, kadar air, dan kadar lemak/minyak sampel kulit ikan pari tersamak dari setiap perlakuan (A, B, C, dan D) telah memenuhi 
persyaratan SNI kulit pari untuk bahan baku barang kulit (SNI 06-6121-1999).

2. Perlakuan $B$ dengan kombinasi bahan penyamak (formalin $4 \%$ dan syntan 8 $\%)$ menghasilkan sampel kulit pari tersamak dengan kualitas terbaik dengan nilai kekuatan tarik 2,810,08 N/ $\mathrm{cm}^{2}$, kekuatan sobek $672,96 \mathrm{~N} / \mathrm{cm}$, suhu kerut $79,67{ }^{\circ} \mathrm{C}$, kadar air $14,99 \%$ dan kadar lemak $4,38 \%$.

\section{Saran}

1. Perlakuan B dapat dipakai sebagai rujukan untuk penyamakan kulit ikan pari tersamak.

2. Diharapkan pada peneliti-penelitian lanjutan menggunakan konsep kombinasi bahan penyamak karena memiliki sifat keunggulan masing-masing dan saling memperbaiki sehingga dapat menghasilkan kulit tersamak dengan kualitas yang lebih baik dibandingkan penggunaan satu jenis bahan penyamak.

\section{DAFTAR PUSTAKA}

Anonim. 2009. Zat-Zat Berbahaya dalam Produk - Produk China. http:/www.chemystri.org, Diakses 20 Agustus 2009.

Ayufita, D. P., 2007. Pengaruh Lama Perendaman Dalam Garam Jenuh Terhadap Kualitas Fisik Kulit Pari Tersamak. Fakultas Pertanian, Universitas Gadjah Mada, Skripsi.

Judoamidjojo, R. M., 1982. Dasar-Dasar Teknologi dan Kimia Kulit, Fakultas Teknologi Hasil Pertanian, Institut Pertanian Bogor.

Judoamidjojo, R. M., 1984. Dasar-Dasar Teknologi dan Kimia Kulit. Penerbit CV. Angkasa Bandung.

Kurniani, A.V., L. Sahubawa, dan B.L. Iwan Yusuf. 2007. Pengaruh Metode Pengawetan Mentah terhadap Kualitas Kulit Pari Tersamak. Prosiding Seminar Nasional Hasil Penelitian Perikanan dan Kelautan Tahun 2007, Jurusan Perikanan Fakultas Pertanian UGM.
SNI-06-6121-1999. Kulit Ikan Pari Untuk Barang Kulit. Dewan Standardisasi Nasional, Jakarta.

Purnomo, E., 2001. Penyamakan Kulit Reptil. Penerbit PT. Kanisius Yogyakarta, Anggota IKAPI.

Poedjiadi, A., 1994. Dasar-Dasar Biokimia. Penerbit Institut Teknologi Bandung.

Sahubawa, L., 2007. Potensi, Strategi Pengembangan serta Kapasitas Imprastruktur Kelautan Perikanan dalam Peningkatan Akses Pemanfaatan Sumberdaya Perikanan Laut Selatan Jawa. Hibah Imprastruktur dan Pengembangan SDM, LPPM UGMIndonesian Facilities.

Sahubawa, L., 2008. Kreasi dan Inovasi Pengembangan Produk Kulit Ikan Berbasis Ekspor. Kajian Peningkatan Nilai Tambah Produk Kulit Ikan dalam Rangka Pengembangan Industri Kreatif Kulit, Bahan Kuliah Teknologi Pengolahan Hasil Perikanan, Jurusan Perikanan Fakultas Pertanian UGM.

Sahubawa, L. dan A. Pertiwiningrum, 2008. Pengembangan Usaha Produk Kulit Ikan Bernilai Ekonomis Penting. Hibah Vucer Pengabdian Masyarakat, Bidang VLPPM UGM, Tahun Anggaran 2008.

Tambunan, P. R., 1992. Perkembangan Penyamakan Kulit Ikan Pari. Prosiding Temu Karya Ilmiah. Pusat Penelitian dan Pengembangan Perikanan. Jakarta.

Untari, S., 1997. Cara-Cara Pengulitan dan Pengawetan Kulit Ikan Pari. Proyek Pengembangan dan Pelayanan Teknologi Industri Kulit, Karet dan Plastik. Balai Besar Penelitian dan Pengembangan Industri Kulit, Karet, dan Plastik. Yogyakarta.

Untari, S., 1997. Penerapan Teknologi Penyamakan Kulit untuk Bahan Tas dengan Sistem Samak Cepat. Balai Besar Kulit, Karet, dan Plastik (BBKKP) Yogyakarta. 